\title{
Impact of acidification and protein fortification on thermal properties of rice, potato and tapioca starches and rheological behaviour of their gels
}

\author{
Marina Villanueva ${ }^{1}$, Felicidad Ronda ${ }^{1}$, Thomas Moschakis ${ }^{2}$, Athina Lazaridou ${ }^{2}$, Costas G. \\ Biliaderis $^{2 *}$
}

(1) Department of Agriculture and Forestry Engineering, Food Technology, College of Agricultural and Forestry Engineering, University of Valladolid, Av. Madrid, 44, 34004 Palencia, Spain.

(2) Department of Food Science and Technology, Faculty of Agriculture, Forestry and Natural Environment, Aristotle University of Thessaloniki, P.O. Box 235, Thessaloniki GR-541 24, Greece

* Corresponding author: biliader@agro.auth.gr; Tel: +302310991797

\begin{abstract}
The impact of acidification and non-gluten protein fortification (egg-albumin and soy-protein isolate) on thermal transitions of rice, potato and tapioca starches as well as the viscoelastic properties of their gels prepared at two casting temperatures, $90^{\circ} \mathrm{C}$ and $120^{\circ} \mathrm{C}$, was investigated. The thermal and rheological behaviour of starches depended on their botanical origin and were significantly influenced by the presence and type of protein added as well as by the $\mathrm{pH}$ of the aqueous dispersion. Acidification to $\mathrm{pH} 4.5$ increased the gelatinization temperature of rice starch in the presence of albumin or soy proteins, while reduced it in the case of tapioca starch, regardless of the presence of proteins. Acidification of rice starch dispersions decreased significantly the apparent gelatinization enthalpy; this effect was even greater in the presence of proteins. The addition of proteins brought about a structuring effect on tapioca gels leading to higher viscoelastic moduli and lower $\tan \delta$ values. In general, acidification led to weaker gel structures, with more pronounced effect for potato starch, most likely related to its higher phosphate content (charge screening). Much weaker gels were obtained at $120^{\circ} \mathrm{C}$ compared to those processed at lower temperatures; however, protein incorporation reinforced gel structure, an effect that was not observed in gels formed at $90^{\circ}$, as also revealed by microstructure analysis using confocal scanning laser microscopy. In conclusion, protein addition and $\mathrm{pH}$ adjustments of aqueous starch dispersions can provide an effective means to modulate the functional and textural properties of gel-like starch-based gluten-free formulations.
\end{abstract}

Keywords: Acidification; starch; Thermal properties; Rheological properties of starch gels; Nongluten proteins; Confocal scanning laser microscopy

\section{Introduction}

Gluten-free (GF) products are a growing processed foods sector and the related research activity constitutes a prioritized and challenging topic in the area of cereal-based products. The development of new GF food items is emerging not only because the daily dietary requirements for essential nutrients of celiac disease patients are not fully met at present by existing products, but also because of industry needs for product diversification (Mandala \& Kapsokefalou, 2011). Moreover, the target group of GF products is currently expanding to include, in addition to 
clinically diagnosed celiac patients (1-3\% of the population), people looking for non-allergenic ingredients, thus leading to a new market product category where a variety of items are being offered to the consumer.

Starch is a macro-constituent in many raw materials and processed foods with particular importance from both a nutritional and a functional point of view; in many formulated products its role is pivotal as texture modifier (Walkenström and Hermansson, 1998), contributing to many quality aspects of processed foods (Chen et al., 2015). Rice, potato and tapioca are among the most commonly used starches for texture development in many gluten-free products. In almost all applications, starchy food matrices are heated and sheared during manufacturing. When the starch granules are heated in the presence of water several changes at a molecular and structural level occur and the ordered (partially crystalline) native granules swell and form a viscous dispersion (Biliaderis, 2009; Carlstedt et al., 2015). The temperature and energy required for these phase transitions are usually probed by differential scanning calorimetry (DSC) that monitors differences in structural organization and phase transition behavior among starches subjected to thermal treatments in aqueous media (Biliaderis, 1983, 2009; Roos, 1995; Singh et al., 2003). During thermal processing-manufacturing and consumption of starchy foods, hydrocolloid gels are formed and they are subjected to large deformations that may cause either irreversible deformation or structural failure due to fracture (Tabilo-Munizaga and Barbosa-Cànovas, 2005). Therefore, the study of rheological properties of starch gels is essential for proper handling and modification of sensory attributes of starch-based foods.

Rice starch is one of the most common ingredients used in GF products (Matos \& Rosell, 2015), although it does not form self-supporting gel networks, even at concentrations above $20 \%$, that are easily disintegrated (Abebe \& Ronda 2014). Starches from tubers and roots, such as potato and tapioca, with notable higher amylose content, are also useful hydrocolloid alternatives in gellike gluten-free formulations (Burrel, 2003).

Several methods to modify texture of starchy foods have been explored. Among them, acidification of rice-based food systems has been tested by means of addition of acetic or lactic acid (Blanco et al., 2011; Kasai et al., 2001) and their blends (Ronda et al., 2014; Villanueva et al., 2015), or their production from lactic acid bacteria fermentation in the form of sourdough (Moore, Del Bello \& Arendt, 2008), which seems to be a promising alternative. Acetic acid increased the transparency, glossiness and stickiness and decreased the hardness of cooked rice (Kasai, Tanihata, Ohishi, Shimada \& Hatae, 2001). Acidification also had an effect on complex systems such as rice based gluten-free doughs (Jekle \& Becker, 2012; Ohishi et al., 2007; Ronda et al., 2014), imparting the quality of the final baked products (Blanco et al., 2011; Jayaram et al., 2014; Villanueva et al., 2015). Moreover, acetic and lactic acids confer acceptable sensorial properties to GF breads in terms of odour and taste, either when produced by a starter culture or added as ingredients in bread formulations, leading to staling retardation (Moore, Del Bello \& Arendt, 2008). This could be attributed to an increase in net protein charge, which enhances protein-solvent interactions and protein unfolding, but eventually prevents formation of a strong network structure, as noted for gluten-based doughs (Jayaram et al., 2014). The higher solubility and degradation of rice flour proteins in acetic acid than in distilled water might also accelerate the absorption, swelling and gelatinization of starch of rice flour (Ohishi et al., 2003).

Incorporation of exogenous proteins is another alternative to improve the final properties (physical, textural and nutritional) of starchy products; i.e. besides polysaccharides, proteins are 
known as structure- and texture-macromolecular modifiers in foods (Da Silva and Rao, 2007). Such enrichment is even more important for gluten-free formulations that usually have a poor protein/starch balance. Soy protein isolate (SPI) and dried egg albumin (EA) have been investigated in GF applications due to their nutritional quality and foam-stabilizing activity (Crockett et al., 2011; Marco \& Rosell, 2008a, 2008b; Ronda et al., 2014; Villanueva et al., 2015). These globular proteins have the ability to heat-set in a gel state where a number of intraand intermolecular disulfide bonds as well as hydrophobic interactions between nonpolar amino acid groups are involved (Chang et al., 2016). The structure of these gels is dependent on both $\mathrm{pH}$ and ionic strength (Brownsey et al., 1989). However, the impact of acidification on proteinenriched starch systems has been little studied. We have previously reported a structure weakening effect by acidification on protein-enriched rice starch bread doughs (Ronda et al., 2014) that led to improved texture of protein-enriched gluten free breads (Villanueva et al., 2015). However, the impact of proteins and the modulating effect of $\mathrm{pH}$ on the thermal properties of starches from different sources as well as the rheological behavior of their gels have not been extensively studied so far. Also, pending and important for the development of autoclaved gellike foods, is the evaluation of the effect of processing temperatures on formation of mixed starch-protein gels and their rheological properties.

Considering all these factors, the aim of the present work was to study the effect of decreasing the $\mathrm{pH}$ of starch dispersions to 4.5 on the thermal properties of rice, potato and tapioca starches and their mixtures with egg white and soybean protein isolate (at $10 \%$ by weight level) and on the rheological properties of their gels prepared at $90^{\circ}$ (common cooking temperatures) and $120^{\circ} \mathrm{C}$ (sterilization temperatures). Evaluation of the microstructure of the starch dispersions and gels was also carried out using confocal laser scanning microscopy (CLSM) for elucidation of their structural features. The knowledge gained from this work may help to modulate the formulation and improve texture of new gel-like gluten-free food products.

\section{Material and methods}

\subsection{Materials}

Rice starch $(9.9 \%$ w/w moisture, $0.5 \%$ protein and $<10 \%$ amylose content referred to total starch) and potato starch $(19.1 \% \mathrm{w} / \mathrm{w}$ moisture, $0.45 \% \mathrm{w} / \mathrm{w}$ protein and $22 \%$ amylose referred to total starch) were supplied by Ferrer Alimentación S.A. (Barcelona, Spain), whereas tapioca starch (13\% moisture, $0.1 \%$ w/w protein, and $17 \%$ amylose content referred to total starch) was supplied by Cargill (Brenntag) S.L. Soy bean protein isolate was Supro 500-E IP (purity 82\%) from Proveedora hispano-holandesa S.A. (Barcelona, Spain) and egg albumin in dry powder form (purity $~ 92 \%$ ) was from Eurovo (Valladolid, Spain). A sodium acetate (100 mM, pH 4.5) buffer was used to acidify the starch-protein dispersions; glacial acetic acid or $1.0 \mathrm{M} \mathrm{NaOH}$ (analytical grade), supplied by Panreac (Barcelona, Spain) were used to adjust the $\mathrm{pH}$ at the desired level. Double-distilled water was used to prepare all the solutions and aqueous hydrocolloid dispersions.

\subsection{Methods}

\subsubsection{Starch dispersions and gel preparation}

Starch gels were made by heating $20 \mathrm{~g}$ of starch or starch+protein blend in $100 \mathrm{~g}$ of suspension in a hermetically sealed cylindrical stainless steel container $(25 \mathrm{~mm}$ inner diameter and $60 \mathrm{~mm}$ height) at 90 or $120^{\circ} \mathrm{C}$. The protein content in the solid starch-protein mixtures was either 0 or 10 $\mathrm{g} / 100 \mathrm{~g}$ of mixture which means 0 or $2 \mathrm{~g}$ of proteins in $100 \mathrm{~g}$ of aqueous dispersion. When the 
buffer was added, the double distilled water was replaced by the $100 \mathrm{mM}$ acetate buffer $(\mathrm{pH}=4.5)$. It was checked and found that in this case, the resultant $\mathrm{pH}$ in the dispersions was always 4.5. Gels were made by immersion of the stainless steel container containing the starch dispersion in a preheated oil bath (at $120^{\circ} \mathrm{C}$ ) or in a water bath (maintained at $90^{\circ} \mathrm{C}$ ) and kept there for 7 min to accomplish gelation of the starch/protein dispersions. During the heating period the device was shaken manually and once the time elapsed, the device was rapidly cooled by immersion in a water bath at $18 \pm 3{ }^{\circ} \mathrm{C}$ for $5 \mathrm{~min}$, without loss of water or any mechanical damage (lack of shear) of the preformed upon heating gel network.

\subsubsection{Thermal properties}

Differential scanning calorimetry (DSC) measurements were carried out with a PL DSC-Gold calorimeter (Polymer Labs. Ltd, Epsom, UK). Samples of about 4.5-6.5 mg dry matter of starch or starch-protein mixtures were dispersed in water or in the acidified medium $(20 \% \mathrm{w} / \mathrm{w}$ dispersions) and sealed hermetically into $120 \mu \mathrm{L}$ DSC medium pressure stainless steel pans (ME29990, Mettler, Toledo, SAE). The dispersions were made either with distilled water or with a $100 \mathrm{mM}$ acetate buffer ( $\mathrm{pH}=4.5$ ). Samples were scanned from 10 to $125^{\circ} \mathrm{C}$ at $5{ }^{\circ} \mathrm{C} / \mathrm{min}$ using an empty pan as reference. The onset, endset, and peak temperatures, $\mathrm{T}_{\mathrm{o}}, \mathrm{T}_{\mathrm{e}}, \mathrm{T}_{\mathrm{p}}\left({ }^{\circ} \mathrm{C}\right)$, or temperature values at which the transition starts, ends or gives the maximum signal, respectively, and the apparent enthalpy, $\Delta \mathrm{H}(\mathrm{J} / \mathrm{g}$ of starch), of starch gelatinization and amylose-lipid dissociation endotherms were evaluated from the thermograms. Reported values are the means of at least duplicate measurements for each system.

\subsubsection{Rheological measurements}

The gel cylinders were cut into slices and placed between the parallel plates (serrated upper plate with $25 \mathrm{~mm}$ diameter) of a Physica MCR 300 rheometer (Physica Messtechnic GmbH, Stuttgart, Germany). Rheological tests were carried out with $1 \mathrm{~mm}$ gap. Before the measurement, the gel was rested for $10 \mathrm{~min}$ to allow sample relaxation. Strain sweeps were carried out from 0.01 to $1000 \%$ strain at $1 \mathrm{~Hz}$ frequency. From strain/stress sweep tests of gels the maximum stress, $\tau_{\max }$, was also calculated as the stress at which the elastic modulus of the gels dropped in the LVR by $10 \%$. Frequency sweeps were carried out from 0.1 to $100 \mathrm{~Hz}$ in the linear viscoelastic region (LVR); the stress value chosen for the frequency sweep tests of all gels was $0.5 \mathrm{~Pa}$, which was in the LVR. A constant temperature of $25^{\circ} \mathrm{C}$ was chosen and maintained by the controlled Peltier system of the rheometer (TEZ 150P/MCR). Data analysis was carried out by the supporting software US200 V2.21 of the rheometer. Frequency sweep data were fitted to the power law model as in previous works (Ronda et al., 2011; 2014). The recorded viscoelastic parameters, $\mathrm{G}_{1}{ }^{\prime}$ and $\mathrm{G}_{1}$ ', and $(\tan \delta)_{1}$, represent the elastic and viscous moduli and the loss tangent, respectively, at a frequency of $1 \mathrm{~Hz}$. The $\mathbf{a}$ and $\mathbf{b}$ exponents quantify the dependence of the dynamic moduli on the oscillation frequency (power law model). Each test was carried out at least in duplicate.

\subsubsection{Confocal Laser Scanning Microscopy}

A Leica TCS SP5 confocal laser scanning microscope (CLSM), mounted on a Leica DMI 6000B inverted microscope base, was operated in the fluorescence mode with a 60x oil- 
immersion objective of numerical aperture 1.40. The starch and protein phases were stained with Nile Blue. Fluorescence from the sample was excited with the $633 \mathrm{~nm}$ of a red HeNe laser line. The signal from the samples was collected and eight scans were averaged for the creation of each image. For granular starches or the mixed starch-protein aqueous dispersions, samples of $\sim 5 \mathrm{ml}$ were transferred into a small beaker. A $10 \mu \mathrm{l}$ aliquot of Nile Blue solution $(0.01 \% \mathrm{w} / \mathrm{v})$ was added and the dispersions were thoroughly mixed. In the case of gels, the starch or starch/protein dispersions were initially stained with the dye and afterwards the gels were formed as described in section 2.2.1.

\subsubsection{Statistical analysis}

Statgraphics Centurion v.6 (Bitstream, Cambridge, MN, USA) allowed performance of ANOVA analysis of the data; the LSD (Least Significant Difference) test was used to evaluate significant differences $(\mathrm{p}<0.05)$ between samples.

\section{Results and discussion}

\subsection{Thermal properties}

The thermal properties of different aqueous starch dispersions (at $20 \% \mathrm{w} / \mathrm{w}$ total solids) as influenced by $\mathrm{pH}$ and the presence of proteins are shown in Figure 1 and Table 1. Potato and tapioca starch exhibited one endothermic peak on the DSC thermograms, while rice starch and its mixtures with proteins showed two peaks; i.e. the main endotherm related to starch gelatinization and a much smaller peak at higher temperature due to the amylose-lipid complex dissociation (Biliaderis 2009; Eliasson, 1994). The temperature values of the latter (second) peak (rather broad transition) appeared slightly lower in the buffered dispersions than in distilled water $\left(83.8^{\circ} \mathrm{C}\right.$, $95.2^{\circ} \mathrm{C}$ and $106.7^{\circ} \mathrm{C}$ versus $84.8^{\circ} \mathrm{C}, 96.1^{\circ} \mathrm{C}$ and $108.1^{\circ} \mathrm{C}$ for $\mathrm{T}_{\mathrm{o}}, \mathrm{T}_{\mathrm{p}}, \mathrm{T}_{\mathrm{e}}$, respectively); the dissociation enthalpies of the amylose-lipid complex in both types of rice starch dispersions (2.1 versus $1.9 \mathrm{~J} / \mathrm{g}$ starch) were not significantly different. For the gelatinization peak, $T_{p}$, the highest temperature corresponded to tapioca $\left(72.6^{\circ} \mathrm{C}\right)$ and the lowest to potato starch $\left(64.5^{\circ} \mathrm{C}\right)$, and an intermediate value for rice starch $\left(68.6^{\circ} \mathrm{C}\right)$ (Table 1). Similar findings were reported by other authors (da Cruz Francisco et al., 1996; Singh et al., 2003). Potato starch exhibited the highest apparent gelatinization enthalpy values $(13.3 \mathrm{~J} / \mathrm{g}$ starch), followed by tapioca starch $(10.6 \mathrm{~J} / \mathrm{g}$ starch), whereas the lowest values corresponded to rice starch suspensions (6.9 J/g starch). The differences observed may be attributed to differences in several factors such as size, shape and distribution of starch granules, amylose/amylopectin ratio (that followed the same order, potato>tapioca $>$ rice, with gelatinization enthalpy values), macromolecular assemblies of starch polymers within the granule and the presence of internal monoacyl lipids, in the case of rice starch, which upon heating form complexes with amylose, an exothermic process that reduces the 'apparent' gelatinization enthalpy of the starch crystallites (Biliaderis, 2009; Schirmer et al., 2013). The enthalpy value reflects the composite thermal energy effect resulting from melting (endothermic) of starch crystallites as well as the amount of heat associated with formation (exothermic) or disruption (endothermic) of short range order (e.g. amylose lipid complexes) in the heated starch matrix (Biliaderis, 2009).

The presence of proteins at the weight ratio used in the mixed systems (10\% with respect to the solid starch-protein mixture) did not seem to significantly alter the $\mathrm{T}_{\text {onset, }}, \mathrm{T}_{\text {peak }}, \mathrm{T}_{\text {end }}$ and $\Delta \mathrm{H}$ of starch gelatinization endotherm (Table 1), although the analysis of variance did show significant 
interaction effects (protein $\mathrm{x}$ starch and starch $\mathrm{x}$ protein $\mathrm{x} \mathrm{pH}$ ) (Table 1); this means that the effect of proteins depended on starch type and $\mathrm{pH}$ of the dispersion. The apparent gelatinization enthalpy values of different starches significantly increased in the presence of soy protein in both pure aqueous (distilled water) and acidified dispersions of potato starch, as well as for egg albumin in the acidified dispersions of tapioca starch, while $\Delta \mathrm{H}$ decreased when both proteins were added in the acidified dispersions of rice starch; no change in $\Delta \mathrm{H}$ values was observed in the remaining mixtures of starches-proteins. It is worth noting that calorimetry of the protein samples alone (25\% w/w aqueous dispersions) did not show any endothermic peak in the DSC thermograms over the same temperature range (data no shown). This means the proteins used in this study were completely denatured as a consequence of their manufacturing process; otherwise some endothermic transitions would instead occur as found for native protein systems (e.g. a double endothermic transition in the case of SPI, corresponding to 7S and 11S globulins of oilseeds and legume seeds, respectively; Biliaderis, 1983).

Acidification of the starch dispersions did not have a significant single effect on the gelatinization thermal transition parameters (Table 1). An influence was only noted, depending on the starch source and the type of starch-protein mixture used, through significant interactions effects (starch $\mathrm{x} \mathrm{pH}$ and starch $\mathrm{x}$ protein $\mathrm{x} \mathrm{pH})$. At $\mathrm{pH} 4.5$, the gelatinization enthalpy of the rice starch suspension was significantly decreased $(\sim 26 \%)$ and this effect was more pronounced in the presence of proteins $(-29 \%$ and $-35 \%$ for EA and SPI, respectively). Similar effects of acidification were recently reported for rice starch by Colussi et al. (2015). However, no significant effects of the acidified medium on potato and tapioca starch gelatinization enthalpy were noted (Table 1). These two tuber starches have similarities between them and differ from rice starch (e.g. significantly higher amylose content and absence of lipids) that could explain their similar behaviour upon acidification versus the rice starch. On the other hand, differences between starches from potato and tapioca, such as the higher phosphorus content and the longer average chain length of amylopectin in the former (da Cruz Francisco et al., 1996), may explain differences between their gelatinization temperature and enthalpy values (Table 1); for tapioca starch higher $T_{o}, T_{p}$, and $T_{e}$ values and lower $\Delta H$ were found compared to those from potato.

The change of the dispersion medium from distilled water to acetate buffer $(\mathrm{pH} 4.5)$ increased the gelatinization temperature, $\mathrm{T}_{\mathrm{p}}$, of rice starch by approximately $2^{\circ} \mathrm{C}$ in the presence of EA or SPI proteins, while it did not exert any effect on pure rice starch dispersions. Ohishi et al. (2007) found that addition of $0.2 \mathrm{M}$ acetic acid resulted in a significantly lower gelatinization temperature $\left(\sim 1^{\circ} \mathrm{C}\right)$ for rice starch obtained from a brown rice japonica variety. The authors attributed this shift to acceleration of water absorption by the starch granules (i.e. promotion of its hydration by adding acetic acid). Hibi (2002) also reported that the endothermic peak temperature of rice starch was lower in the presence of $0.33 \mathrm{M}$ acetic acid. In both previous cases the resultant $\mathrm{pH}$ of the heated starch dispersions was not reported by the authors, but it should be lower than that of the present study, where the rice starch dispersion was adjusted to $\mathrm{pH} 4.5$; this might explain why we did not observe any effect on gelatinization temperature for the pure rice starch dispersions. In contrast, acidification of tapioca starch dispersions facilitated the gelatinization, as demonstrated by the lower onset and peak temperatures of the acidified starch samples, compared to their distilled water counterparts, regardless the presence or absence of proteins (Table 1). Acidification of tapioca starch also led to a wider gelatinization range, i.e. $\left(\mathrm{T}_{\mathrm{e}}-\mathrm{T}_{\mathrm{o}}\right)$ difference, implying a more complex phase transition behaviour (Table 1 and Figure 1). 
Table 1. Starch gelatinization parameters of rice, potato and tapioca starches and their mixtures with egg albumin and soy protein isolate in aqueous (distilled water) and $\mathrm{pH} 4.5$ (acetate buffer $100 \mathrm{mM})$ dispersions $(20 \% \mathrm{w} / \mathrm{w})$.

\begin{tabular}{|c|c|c|c|c|c|c|}
\hline Starch & Protein & $\begin{array}{l}\text { Acetate } \\
\text { Buffer }\end{array}$ & $\mathbf{T}_{\mathbf{o}}\left({ }^{\circ} \mathrm{C}\right)$ & $\mathbf{T}_{\mathrm{p}}\left({ }^{\circ} \mathrm{C}\right)$ & $\mathrm{T}_{\mathrm{e}}\left({ }^{\circ} \mathrm{C}\right)$ & $\Delta \mathbf{H}(\mathrm{J} / \mathrm{g}$ starch $)$ \\
\hline \multirow[t]{6}{*}{ Rice } & 0 & 0 & $60.3 \mathrm{abcd}$ & $68.6 \mathrm{c}$ & $77.2 \mathrm{bcd}$ & $6.9 \mathrm{~b}$ \\
\hline & & 1 & $59.9 \mathrm{abc}$ & $68.8 \mathrm{c}$ & 77.0 bcd & $5.2 \mathrm{a}$ \\
\hline & EA & 0 & 59.9 abcd & $68.9 \mathrm{c}$ & $77.8 \mathrm{~cd}$ & $7.0 \mathrm{~b}$ \\
\hline & & 1 & $63.5 \mathrm{fgh}$ & 70.7 de & $77.6 \mathrm{~cd}$ & $5.0 \mathrm{a}$ \\
\hline & SPI & 0 & 61.0 bcdef & $68.4 \mathrm{c}$ & $78.1 \mathrm{~d}$ & $7.8 \mathrm{bc}$ \\
\hline & & 1 & 62.1 cdefg & $70.1 \mathrm{~d}$ & 76.9 bcd & 5.1 a \\
\hline \multirow[t]{6}{*}{ Potato } & 0 & 0 & $59.3 \mathrm{ab}$ & 64.5 a & $75.9 \mathrm{bc}$ & $13.3 \mathrm{hij}$ \\
\hline & & 1 & $59.6 \mathrm{abc}$ & $64.9 \mathrm{ab}$ & 78.7 de & 13.7 ij \\
\hline & EA & 0 & $59.3 \mathrm{ab}$ & $64.7 \mathrm{ab}$ & $75.2 \mathrm{~b}$ & $14.3 \mathrm{jk}$ \\
\hline & & 1 & 57.9 a & $64.2 \mathrm{a}$ & $72.4 \mathrm{a}$ & $14.6 \mathrm{jk}$ \\
\hline & SPI & 0 & 60.1 abcd & $64.5 \mathrm{ab}$ & $78.5 \mathrm{~d}$ & $15.4 \mathrm{kl}$ \\
\hline & & 1 & 60.5 abcde & $65.5 \mathrm{~b}$ & 80.8 ef & 16.61 \\
\hline \multirow[t]{6}{*}{ Tapioca } & 0 & 0 & 63.1 efgh & $72.6 \mathrm{f}$ & $81.2 \mathrm{f}$ & $10.6 \mathrm{def}$ \\
\hline & & 1 & $60.3 \mathrm{abcd}$ & 70.6 de & $82.2 \mathrm{f}$ & $9.3 \mathrm{~cd}$ \\
\hline & EA & 0 & $64.0 \mathrm{gh}$ & $72.8 \mathrm{f}$ & $82.9 \mathrm{f}$ & $11.8 \mathrm{fgh}$ \\
\hline & & 1 & $62.6 \mathrm{defg}$ & $71.3 \mathrm{e}$ & $85.5 \mathrm{~g}$ & 12.4 ghi \\
\hline & SPI & 0 & $65.3 \mathrm{~h}$ & $73.0 \mathrm{f}$ & $83.1 \mathrm{f}$ & $11.2 \mathrm{efg}$ \\
\hline & & 1 & 61.0 bcdef & 70.9 de & $82.3 \mathrm{f}$ & $9.7 \mathrm{de}$ \\
\hline SE & & & 0.90 & 0.36 & 0.77 & 0.56 \\
\hline
\end{tabular}

\begin{tabular}{lcccc}
\hline \multicolumn{5}{c}{ Analysis of variance and significance (p-values) } \\
\hline Factor 1 (starch) & $* * *$ & $* * *$ & $* * *$ & $* * *$ \\
Factor 2 (protein type) & $\mathrm{ns}$ & $\mathrm{ns}$ & $\mathrm{ns}$ & $\mathrm{ns}$ \\
Factor 3 (pH) & $\mathrm{ns}$ & $\mathrm{ns}$ & $\mathrm{ns}$ & $\mathrm{ns}$ \\
Factor 1x2 & $\mathrm{ns}$ & $\mathrm{ns}$ & $* * *$ & $*$ \\
Factor 1x3 & $* *$ & $* * *$ & $\mathrm{~ns}$ & $* *$ \\
Factor 2x3 & $\mathrm{ns}$ & $\mathrm{ns}$ & $\mathrm{ns}$ & $\mathrm{ns}$ \\
Factor & $* * *$ & $* * *$ & $* * *$ & $* * *$ \\
$1 \times 2 \times 3$ & & & & \\
\hline
\end{tabular}

Protein: 0: without protein; EA: egg albumen; SPI: soy protein isolate. Acetate buffer $(\mathrm{pH}=4.5)$ : 0 : without acetate buffer (aqueous medium); 1: Acetate buffer medium. Different letters in the corresponding column indicate statistically significant differences between means at $p<0.05$. SE: Pooled standard error obtained from ANOVA analysis. Analysis of variance and significance: $* * * \mathrm{p}<0.001$. ${ }^{* *} \mathrm{p}<0.01{ }^{*} \mathrm{p}<0.05$. ns: not significant. 

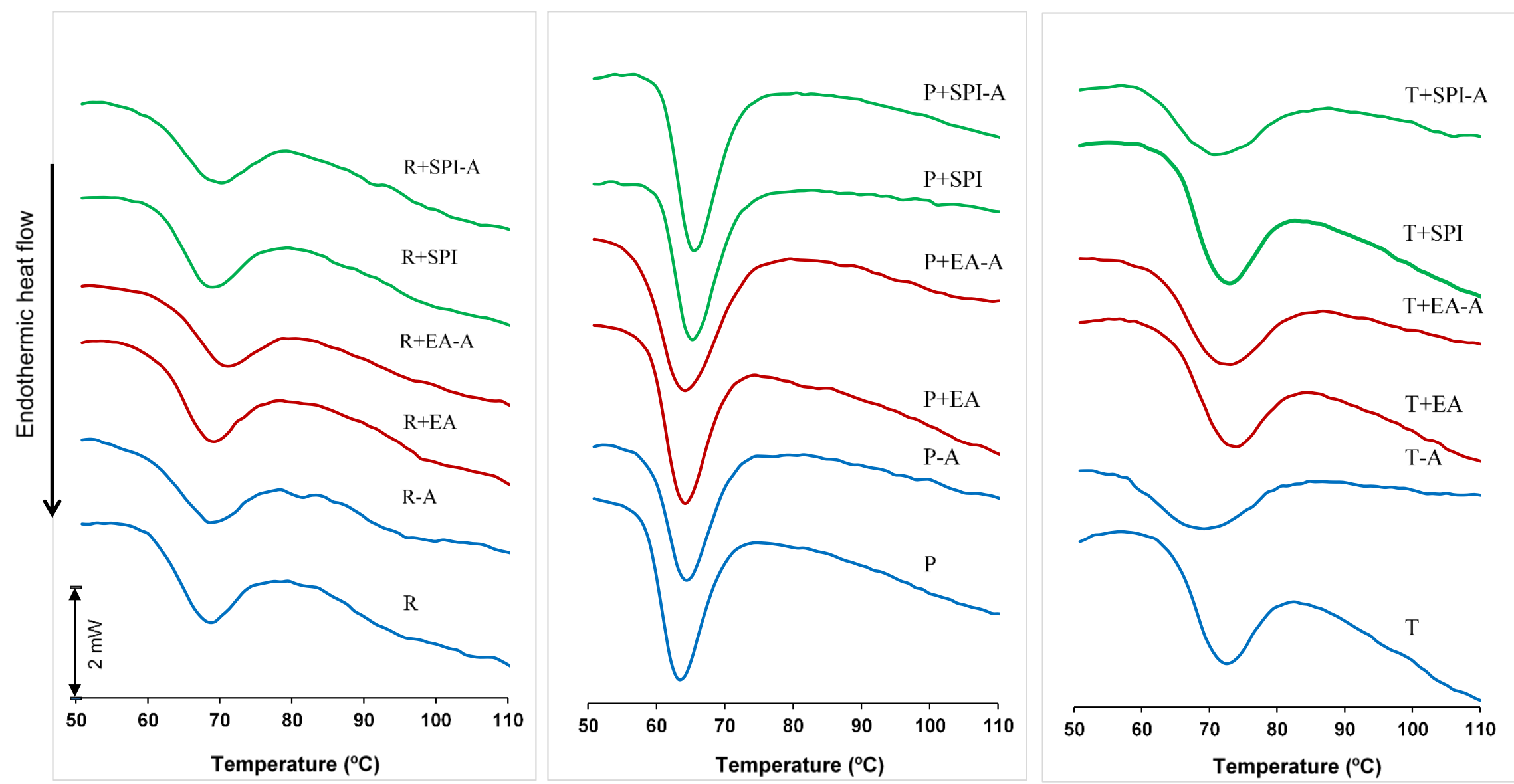

Figure 1. DSC thermograms obtained from aqueous (distilled water) or acidified (acetate buffer $0,1 \mathrm{M} \mathrm{pH} 4.5$ ) dispersions of different starches (rice, potato and tapioca) and their mixtures with proteins (egg albumen or soy protein isolate). R: rice starch; P: potato starch; and T: tapioca starch. EA: egg albumin; SPI: soy protein isolate. -A: Acidified dispersion. 


\subsection{Rheological properties}

\subsubsection{Strain sweeps}

The responses of viscoelastic moduli of starch gels, prepared at $90^{\circ} \mathrm{C}$ and $120^{\circ} \mathrm{C}$ as a function of strain are shown in Figures 2 and 3, respectively. In rice starch gels it was possible to discriminate two different regions, the linear viscoelastic region in which $G^{\prime}$ and $\tan \delta$ (data not shown) values were practically constant, and the non-linear domain in which G' started to decrease, and at the same time the $\tan \delta$ began to increase with increasing strain until the curves of $G^{\prime}$ and $G^{\prime}$ " intersected $(\tan \delta=1)$. However, for tapioca $\left(\right.$ at $90^{\circ} \mathrm{C}$ and $120^{\circ} \mathrm{C}$ ) and potato starch (at $\left.120^{\circ} \mathrm{C}\right)$ gels, the loss tangent was maintained well below 1 over the entire strain range, revealing no cross-over of the G' and G'" curves. The maximum stress, $\tau_{\max }$, that gels can resist before structure disruption (end of LVR) is depicted in Table 2.

Figures 2 and 3 show that the elastic modulus (G') of pure rice gels (formed at both $90^{\circ} \mathrm{C}$ and $120^{\circ} \mathrm{C}$ ) yielded at lower strain values than tapioca and potato starch gels, indicating a more susceptible structure which breaks easier under the applied stress than those of tuber starch gels. In fact, it was not possible to determine the maximum stresses, $\tau_{\max }$, of the latter gels over the entire strain range recorded. Rice starch gels formed at $90^{\circ} \mathrm{C}$ raised their $\tau_{\max }$ values with EA protein addition (Table 2). On the other hand, fortification with SPI and acidification $(\mathrm{pH}=4.5)$ of starch gels prepared at $90^{\circ} \mathrm{C}$ and $120^{\circ} \mathrm{C}$ did not significantly affect this parameter. With increasing gel setting temperature there was decreased gel resistance to breakage; i.e. much lower $\tau_{\max }$ (between $35 \%$ and $100 \%$ decreased values) for gels formed at $120^{\circ} \mathrm{C}$ than their respective samples prepared at $90^{\circ} \mathrm{C}$. Previous works showed similar effects and reported a significant decrease of the rigidity and strength of gels when prepared at autoclaving temperatures (Christianson et al., 1986; Doublier et al., 1987). Due to the high solids content of the heated aqueous starch dispersions ( $20 \% \mathrm{w} / \mathrm{w}$ ) and the lack of shear forces during heat-setting of the gel network structures it is unlikely that extensive phase separation involving amylose leaching out of the swollen granules takes place. However, chain ordering (short scale crystallization) of the linear starch fraction in the high temperature casted gels, forming the continuous phase, could be more pronounced and it might contribute to the observed weakening of the network structure for these samples (Biliaderis, 2009). In the mixed gels, the included proteins most likely partition at the intergranular regions following swelling of the granules upon gel setting.

\subsubsection{Frequency sweeps}

The viscoelastic moduli at $1 \mathrm{~Hz}, \mathrm{G}_{1}$ ', $\mathrm{G}_{1}$ ", and $(\tan \delta)_{1}$ and the obtained exponent "a" and "b" values by fitting the power law model to the frequency sweep data (from 0.01 to $10 \mathrm{~Hz}$ ) are summarized in Table 2. Frequency sweeps showed that G' exceeded G' over the entire frequency range for all the gels tested, with the tan $\delta$ values being low enough (Table 2) to classify such rheological responses as being of "true" gels (Krystyjan et al., 2015; Ribotta and Rosell, 2010). The natural logarithms of $\mathrm{G}_{1}$ ' and $\mathrm{G}_{1}$ " were used for the ANOVA analysis, allowing more conclusive results on the impact of the studied factors (Ronda et al., 2011). 


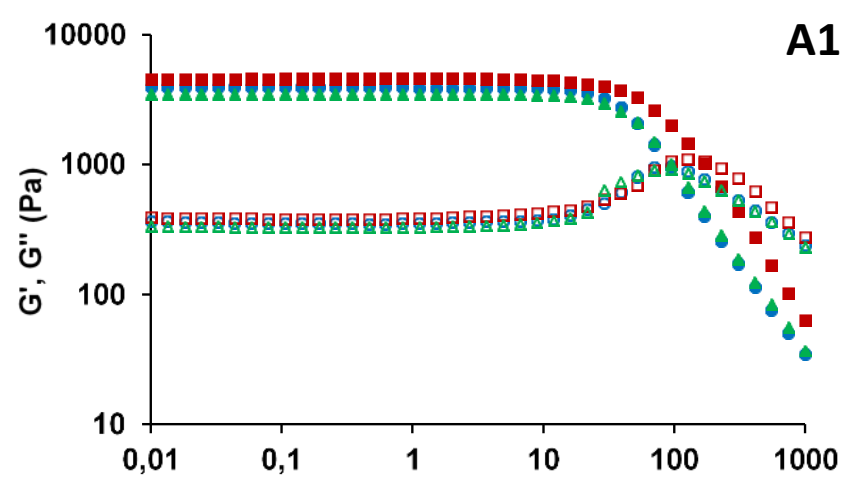

A1
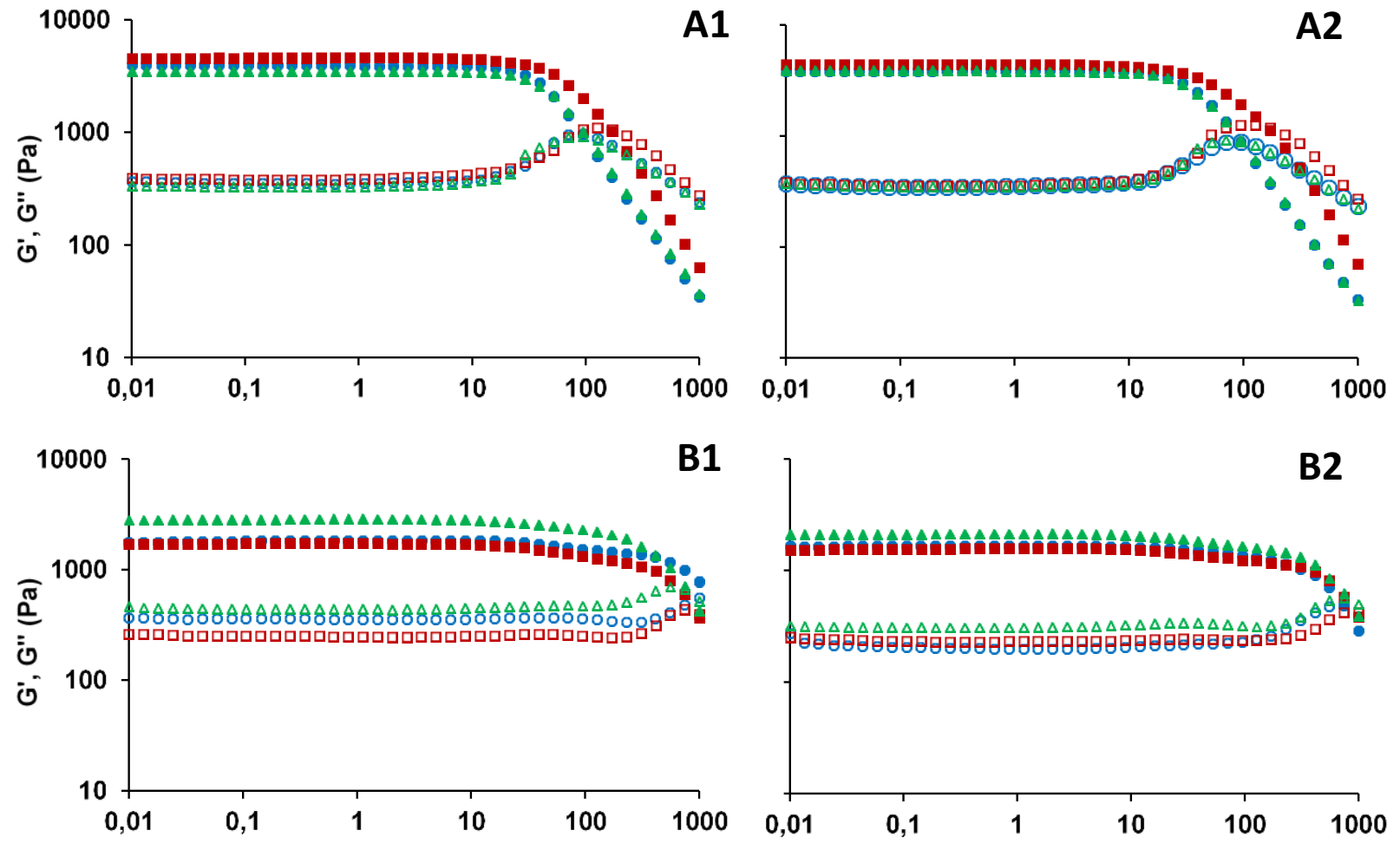

B1
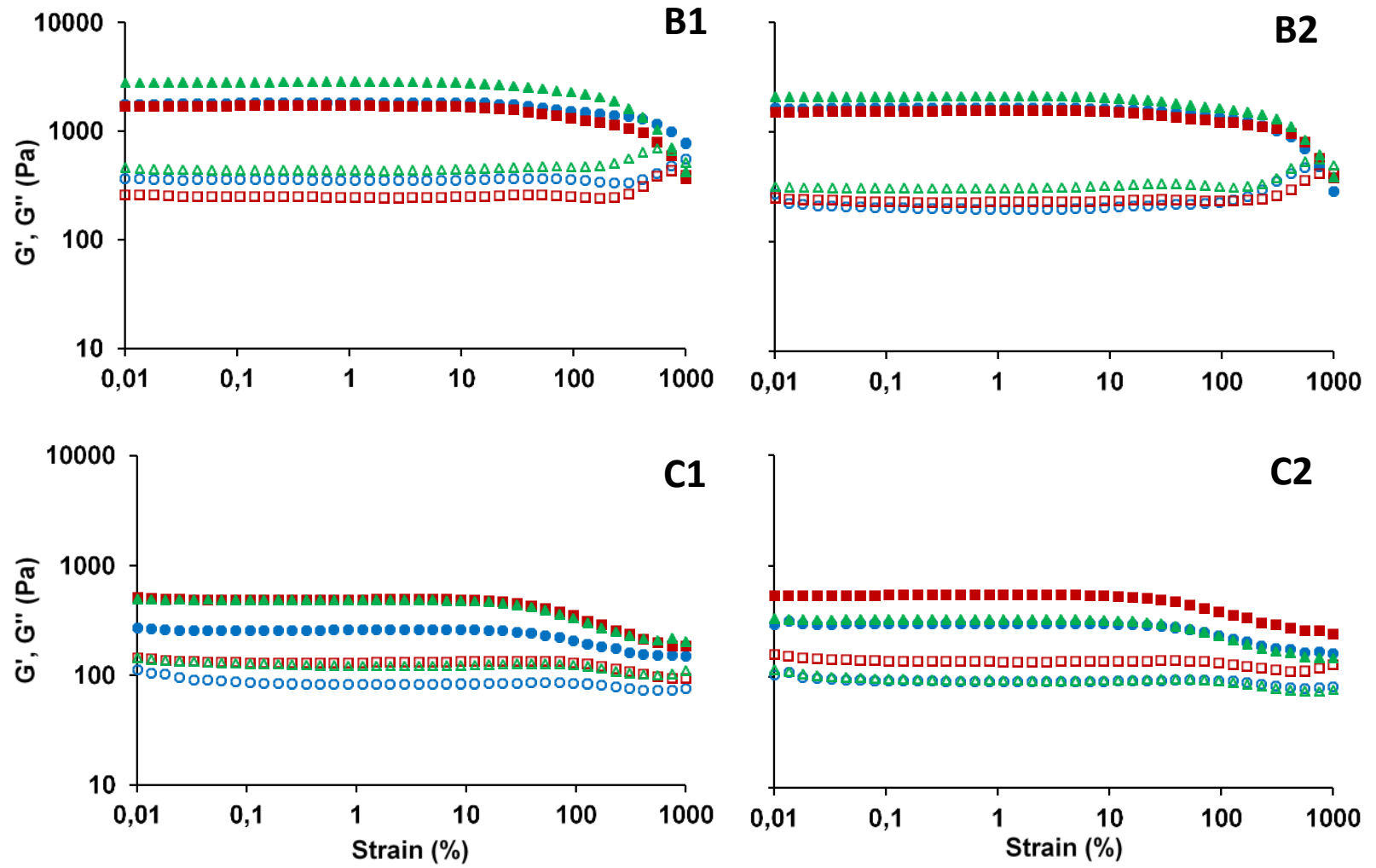

Figure 2: Strain sweeps of rice (A), potato (B) and tapioca (C) starch gels prepared at $90^{\circ} \mathrm{C}$ using distilled water (A1, B1, C1) and acetate buffer (pH 4.5) (A2, B2, C2), without protein addition (circle symbols), with egg albumin (square symbols) or soy protein isolate (triangle symbols). Elastic modulus, G', is represented by solid symbols and viscous modulus, G', by open symbols. 

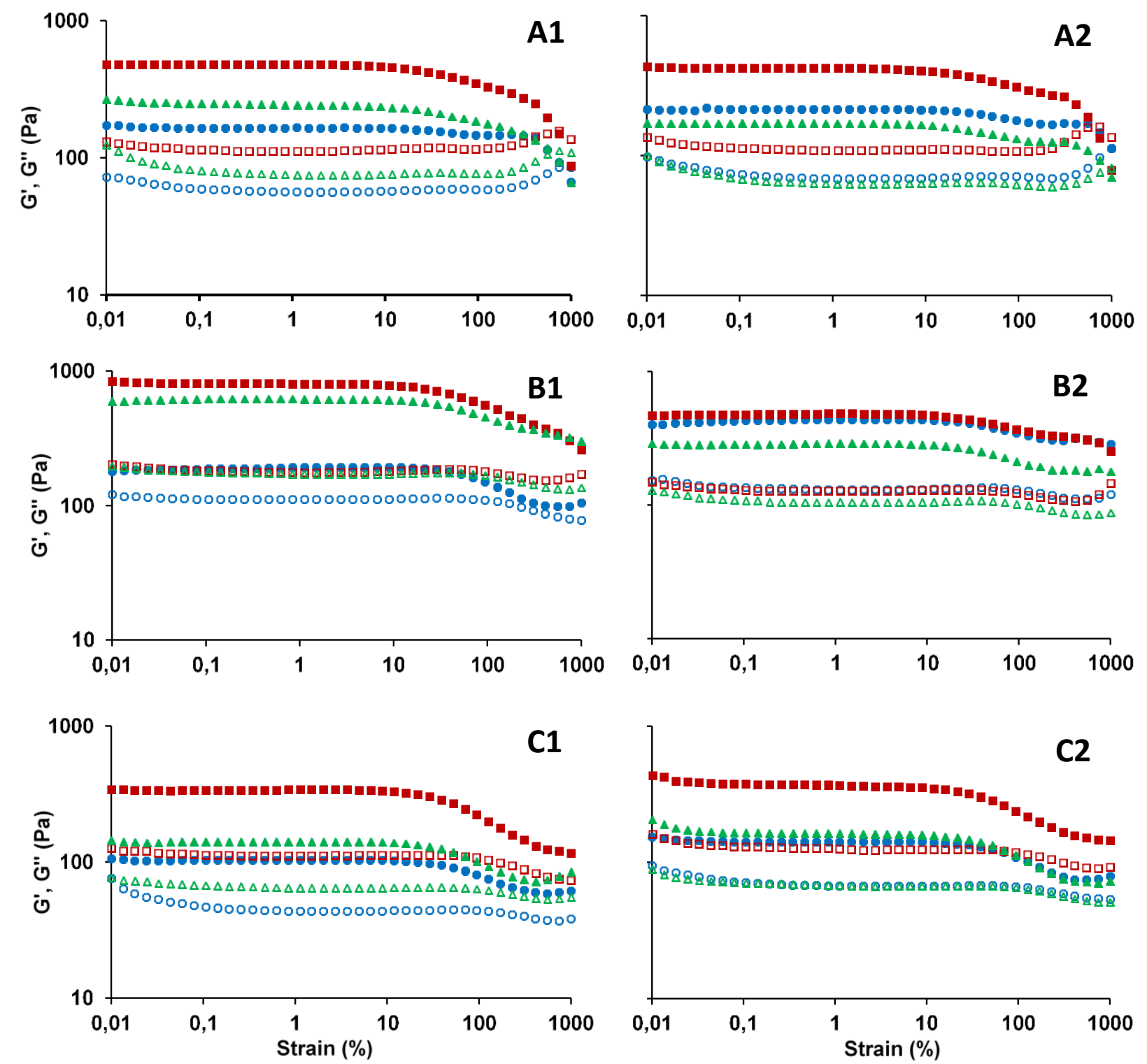

Figure 3: Strain sweeps of rice (A), potato (B) and tapioca (C) starch gels prepared at $120^{\circ} \mathrm{C}$ using distilled water (A1, B1, C1) and acetate buffer (pH 4.5) (A2, B2, C2), without protein addition (circle symbols), with egg albumin (square symbols) or with soy protein isolate (triangle symbols). Elastic modulus, G' is represented by solid symbols and viscous modulus, G', by open symbols. 
The elastic and viscous moduli were much higher in gels formed at $90^{\circ} \mathrm{C}$ than their counterparts formed at $120^{\circ} \mathrm{C}$, whereas the loss tangent increased markedly showing a transition from a 'rigid' ( $\tan \delta_{1} \sim 0.1$ ) to a 'weak' $\left(\tan \delta_{1} \sim 0.4\right)$ type of gels with increase of casting temperature (Table 2). Christianson et al. (1986) found that rice, corn and wheat starch gels prepared at $121^{\circ} \mathrm{C}$ had a much higher fraction of starch molecules released from the gel (obtained in the hot filtrate), not solubilized but rather dispersed, than when the temperature was $80^{\circ} \mathrm{C}$ or $94^{\circ} \mathrm{C}$. This could be attributed to the 'weakening' of the gel structure due to extended deformation and rupture of the swollen starch granules, allowing demixing of the two starch polymeric fractions (amylose and amylopectin) that could count for the lower consistency of gels prepared at $120^{\circ} \mathrm{C}$.

\subsubsection{Viscoelasticity of gels prepared at "cooking” temperatures $\left(90^{\circ} \mathrm{C}\right)$}

Rice starch provided gels with the highest consistency (3182-5094Pa for $\left.\mathrm{G}_{1}{ }^{\prime}\right)$, particularly when compared to tapioca starch; these results concur with the findings of Ronda et al. (2011), who observed the highest moduli for layer cake batters made from rice starch compared to potato, corn and wheat starches.

The rheological properties of gels prepared from the protein-starch blends also showed significant interaction effects (starch $\mathrm{x}$ protein) (Table 2), suggesting that the same protein exerted different effect depending on the starch source. Ribotta and Rosell (2010) observed different effects of SPI on the viscoelastic properties of corn and tapioca starch gels, demonstrating an increase in G' and G' and a decrease in $\tan \delta$ of tapioca starch gels as a result of SPI addition that was not noted in the case of corn starch gels. The data of the present study pointed to a similar impact of SPI on tapioca and potato starch gels, and just an opposite effect on rice starch gels (Table 2). With the EA addition, there was a significant increase in the elastic and viscous moduli of rice starch gels, while it decreased potato gels consistency. Tapioca gels, which were the less structured and exhibited viscoelastic moduli five to ten times below those of the potato and rice starch gels, showed a significant increase of consistency when both proteins, SPI and EA, were added (with increases up to $\sim 70 \%$ in $\mathrm{G}_{1}{ }^{\prime}$ and $\sim 47 \%$ in $\mathrm{G}_{1}{ }^{\prime}$ " values).

Acidification of starch dispersions to $\mathrm{pH} 4.5$ always weakened potato gels prepared at $90^{\circ} \mathrm{C}$, regardless the presence and type of protein added. However, only the SPI-enriched tapioca and rice gels exhibited a significant change in consistency, with a notable decrease in $\mathrm{G}_{1}$ ' and $\mathrm{G}_{1}$ ", moduli, as a consequence of dispersion acidification. The effect of $\mathrm{pH}$ on viscoelasticity of SPIadded gels was dependent on starch source, which concurs with the significant interaction effect found ( $\operatorname{starch} \mathrm{x}$ protein $\mathrm{x} \mathrm{pH}$ ). Acidification of SPI-starch dispersion promotes a change in the collective charge of soybean protein ( $\mathrm{pI}$ 4.5-5.0) leading to decreased strength of the proteinprotein interactions and an increase in the surface of contact with the medium (Ribotta and Rosell, 2010). The different effects of acidification on viscoelastic properties, depending on starch source, were also related to the phosphate groups present in some tuber starches; potato starch exhibits the highest content of phosphate ester residues (Hoover, 2001). 
Table 2. Rheological properties of gels of rice, potato and tapioca starches and their mixtures with egg albumin and soy protein isolate prepared from both aqueous (distilled water) and $\mathrm{pH} 4.5$ buffered dispersions at two different temperatures; all viscoelastic parameters were measured at $25^{\circ} \mathrm{C}$.

\begin{tabular}{|c|c|c|c|c|c|c|c|c|c|c|c|c|c|c|}
\hline \multirow{2}{*}{ Starch } & \multirow{2}{*}{ Protein } & \multirow{2}{*}{$\begin{array}{l}\text { Acetate } \\
\text { Buffer }\end{array}$} & \multicolumn{2}{|c|}{$\mathrm{G}_{\mathbf{1}}{ }^{\prime}(\mathrm{Pa})$} & \multicolumn{2}{|c|}{$\mathbf{a}$} & \multicolumn{2}{|c|}{$\mathrm{G}_{1}{ }^{\prime \prime}(\mathrm{Pa})$} & \multicolumn{2}{|c|}{ b } & \multicolumn{2}{|c|}{$\tan \delta_{1}$} & \multicolumn{2}{|c|}{$\tau_{\max }(\mathbf{P a})$} \\
\hline & & & $90^{\circ} \mathrm{C}$ & $120^{\circ} \mathrm{C}$ & $90^{\circ} \mathrm{C}$ & $120^{\circ} \mathrm{C}$ & $90^{\circ} \mathrm{C}$ & $120^{\circ} \mathrm{C}$ & $90^{\circ} \mathrm{C}$ & $120^{\circ} \mathrm{C}$ & $90^{\circ} \mathrm{C}$ & $120^{\circ} \mathrm{C}$ & $90^{\circ} \mathrm{C}$ & $120^{\circ} \mathrm{C}$ \\
\hline \multirow[t]{6}{*}{ Rice } & 0 & $0(6.39)$ & $3955 \mathrm{i}$ & $212 b$ & $0.057 \mathrm{a}$ & $0.187 \mathrm{c}$ & 373 hij & $70 \mathrm{bc}$ & $0.306 \mathrm{~h}$ & $0.362 \mathrm{cdef}$ & $0.094 \mathrm{bc}$ & $0.334 \mathrm{def}$ & $1196 \mathrm{a}$ & $886 \mathrm{ab}$ \\
\hline & & 1 & $4090 \mathrm{i}$ & $199 \mathrm{~b}$ & $0.055 \mathrm{a}$ & $0.187 \mathrm{c}$ & $381 \mathrm{ijk}$ & $66 \mathrm{~b}$ & $0.306 \mathrm{~h}$ & $0.368 \mathrm{def}$ & $0.093 \mathrm{abc}$ & $0.333 \mathrm{de}$ & $1102 \mathrm{a}$ & $1264 \mathrm{~b}$ \\
\hline & EA & $0(6.68)$ & $4697 \mathrm{j}$ & $615 \mathrm{~g}$ & $0.053 \mathrm{a}$ & $0.131 \mathrm{a}$ & $402 \mathrm{jk}$ & $132 \mathrm{fgh}$ & $0.192 \mathrm{a}$ & $0.281 \mathrm{a}$ & $0.085 a b$ & $0.217 \mathrm{a}$ & $2159 \mathrm{~b}$ & $1061 \mathrm{ab}$ \\
\hline & & 1 & $5094 j$ & $502 \mathrm{fg}$ & $0.053 \mathrm{a}$ & $0.137 \mathrm{ab}$ & $421 \mathrm{k}$ & $124 \mathrm{efg}$ & $0.200 \mathrm{bc}$ & $0.305 \mathrm{ab}$ & $0.083 \mathrm{a}$ & $0.245 \mathrm{ab}$ & $2192 b$ & $1232 \mathrm{~b}$ \\
\hline & SPI & $0(7.07)$ & $3182 \mathrm{~h}$ & $282 \mathrm{c}$ & $0.061 \mathrm{a}$ & $0.180 \mathrm{c}$ & $314 \mathrm{~g}$ & $88 \mathrm{~d}$ & $0.274 \mathrm{f}$ & $0.336 \mathrm{bcd}$ & $0.099 \mathrm{c}$ & 0.312 cde & $1239 \mathrm{a}$ & $600 \mathrm{a}$ \\
\hline & & 1 & $3668 \mathrm{i}$ & $186 \mathrm{~b}$ & $0.058 \mathrm{a}$ & $0.186 \mathrm{c}$ & $354 \mathrm{hi}$ & $67 \mathrm{bc}$ & $0.296 \mathrm{~g}$ & 0.365 def & $0.095 \mathrm{bc}$ & 0.360 efg & $1101 \mathrm{a}$ & $793 \mathrm{ab}$ \\
\hline \multirow[t]{6}{*}{ Potato } & 0 & $0(7.34)$ & $2375 \mathrm{~g}$ & $377 \mathrm{de}$ & $0.099 \mathrm{c}$ & $0.231 \mathrm{e}$ & $346 \mathrm{gh}$ & $152 \mathrm{i}$ & $0.205 \mathrm{c}$ & $0.345 \mathrm{~cd}$ & $0.157 \mathrm{e}$ & $0.423 \mathrm{ij}$ & nd & nd \\
\hline & & 1 & $1862 \mathrm{~d}$ & $600 \mathrm{~g}$ & $0.078 \mathrm{~b}$ & $0.135 \mathrm{ab}$ & $229 d$ & $139 \mathrm{ghi}$ & $0.221 \mathrm{~d}$ & $0.309 \mathrm{ab}$ & $0.124 \mathrm{~d}$ & $0.236 \mathrm{ab}$ & nd & nd \\
\hline & EA & $0(6.73)$ & $2109 \mathrm{fg}$ & $504 \mathrm{fg}$ & $0.083 b c$ & $0.161 \mathrm{abc}$ & $271 \mathrm{f}$ & $142 \mathrm{hi}$ & $0.196 a b$ & $0.305 \mathrm{ab}$ & $0.129 \mathrm{~d}$ & $0.285 \mathrm{bcd}$ & nd & nd \\
\hline & & 1 & $1867 \mathrm{de}$ & $474 \mathrm{f}$ & $0.080 \mathrm{~b}$ & $0.162 \mathrm{abc}$ & $238 \mathrm{de}$ & 139 fghi & $0.200 \mathrm{bc}$ & $0.336 \mathrm{bcd}$ & $0.127 \mathrm{~d}$ & $0.307 \mathrm{cde}$ & nd & nd \\
\hline & SPI & $0(7.20)$ & $3014 \mathrm{~h}$ & $317 \mathrm{~cd}$ & $0.080 \mathrm{~b}$ & $0.227 \mathrm{de}$ & $380 \mathrm{ij}$ & $120 \mathrm{ef}$ & $0.192 \mathrm{ab}$ & 0.359 cde & $0.126 \mathrm{~d}$ & 0.388 fghi & nd & nd \\
\hline & & 1 & $2197 \mathrm{ef}$ & $561 \mathrm{fg}$ & $0.078 \mathrm{~b}$ & $0.143 \mathrm{ab}$ & $257 \mathrm{ef}$ & $141 \mathrm{ghi}$ & $0.199 \mathrm{bc}$ & $0.311 \mathrm{ab}$ & $0.123 \mathrm{~d}$ & $0.259 \mathrm{abc}$ & nd & nd \\
\hline \multirow[t]{6}{*}{ Tapioca } & 0 & $0(4.94)$ & $336 a$ & $125 \mathrm{a}$ & $0.157 \mathrm{e}$ & $0.275 \mathrm{f}$ & $99 a$ & $56 \mathrm{a}$ & $0.314 \mathrm{i}$ & $0.396 \mathrm{fg}$ & $0.294 \mathrm{gh}$ & $0.446 \mathrm{jk}$ & nd & nd \\
\hline & & 1 & $320 \mathrm{a}$ & $134 \mathrm{a}$ & $0.169 \mathrm{e}$ & 0.251 ef & $97 \mathrm{a}$ & $66 \mathrm{bc}$ & $0.321 \mathrm{i}$ & $0.413 \mathrm{~g}$ & $0.303 \mathrm{~h}$ & $0.488 \mathrm{k}$ & nd & nd \\
\hline & EA & $0(6.77)$ & $570 \mathrm{bc}$ & 428 ef & $0.141 \mathrm{~d}$ & $0.167 \mathrm{bc}$ & $145 \mathrm{c}$ & $141 \mathrm{ghi}$ & $0.266 \mathrm{e}$ & $0.303 \mathrm{ab}$ & $0.253 \mathrm{f}$ & $0.325 \mathrm{de}$ & nd & nd \\
\hline & & 1 & $604 c$ & $290 c$ & $0.138 \mathrm{~d}$ & $0.193 \mathrm{~cd}$ & $150 \mathrm{c}$ & $110 \mathrm{e}$ & $0.275 \mathrm{f}$ & 0.358 cde & $0.246 \mathrm{f}$ & $0.364 \mathrm{efgh}$ & nd & nd \\
\hline & SPI & $0(7.19)$ & $514 \mathrm{~b}$ & $183 \mathrm{~b}$ & $0.138 \mathrm{~d}$ & $0.233 \mathrm{e}$ & $132 \mathrm{~b}$ & $77 \mathrm{~cd}$ & $0.276 \mathrm{f}$ & $0.329 \mathrm{bc}$ & $0.256 \mathrm{f}$ & 0.418 hij & nd & nd \\
\hline & & 1 & $348 \mathrm{a}$ & $184 \mathrm{~b}$ & $0.166 \mathrm{e}$ & $0.233 \mathrm{e}$ & $99 a$ & $74 \mathrm{bc}$ & $0.307 \mathrm{~h}$ & $0.381 \mathrm{efg}$ & $0.285 \mathrm{~g}$ & 0.405 ghij & nd & nd \\
\hline \multicolumn{3}{|l|}{ SE } & 99 & 36 & 0.005 & 0.012 & 11 & 7 & 0.003 & 0.013 & 0.004 & 0.02 & 150 & 184 \\
\hline \multicolumn{15}{|c|}{ Analysis of variance and significance (p-values) } \\
\hline \multicolumn{3}{|c|}{ Factor 1 (starch) } & $* * *$ & $* * *$ & $* * *$ & $* * *$ & $* * *$ & $* * *$ & $* * *$ & $* *$ & $* * *$ & $* * *$ & ns & ns \\
\hline \multicolumn{3}{|c|}{ Factor 2 (protein type) } & ns & $* * *$ & $\mathrm{~ns}$ & $* * *$ & $\mathrm{~ns}$ & $* * *$ & $* * *$ & $* * *$ & ns & $* * *$ & $* * *$ & $\mathrm{~ns}$ \\
\hline \multicolumn{3}{|c|}{ Factor $3(\mathrm{pH})$} & ns & ns & ns & * & ns & $\mathrm{ns}$ & ns & ns & ns & $\mathrm{ns}$ & ns & ns \\
\hline \multicolumn{3}{|c|}{ Factor $1 \times 2$} & $* * *$ & $* * *$ & $*$ & ns & $* * *$ & $* * *$ & $* * *$ & $* *$ & $* * *$ & ns & nd & nd \\
\hline \multicolumn{3}{|c|}{ Factor $1 \times 3$} & $* *$ & $* * *$ & $*$ & $* * *$ & $* * *$ & $\mathrm{~ns}$ & $\mathrm{~ns}$ & $* *$ & $*$ & $* * *$ & nd & nd \\
\hline \multicolumn{3}{|c|}{ Factor $2 \times 3$} & ns & ns & $\mathrm{ns}$ & $*$ & ns & ns & ns & ns & ns & $*$ & $\mathrm{~ns}$ & ns \\
\hline \multicolumn{3}{|c|}{ Factor $1 \times 2 \times 3$} & $* * *$ & $* * *$ & $* * *$ & $* * *$ & $* * *$ & $* * *$ & $* * *$ & $* * *$ & $* * *$ & $* * *$ & nd & nd \\
\hline
\end{tabular}


The granular shape and size, the presence of lipids (phospholipids) and phosphate monoester residues on amylopectin, and the amylose content seem to be among the most important factors that significantly affect the rheological properties of different starch gels (Biliaderis, 2009; Singh et al., 2003). The effect of $\mathrm{pH}$ on the viscosity of potato starch gels could arise from formation of a counter-ion layer at the phosphate groups on the surface of the potato starch granules (Muhrbeck and Eliasson, 1987). These counter-ions diminish the electric charge of the starch molecules, thus blocking the extensive repulsion forces among the phosphate groups. This was not the case for tapioca starch gels, where the viscoelastic properties were not largely affected by the $\mathrm{pH}$; apparently, tapioca starch has much lower phosphate content than potato starch (Hoover, 2001).

The loss tangent of rice starch gels was below 0.1 for all tested samples (Table 2), implying a well physically cross-linked network structure. The very low values of "a" exponent, near zero, for rice and potato starch gels mean that the elastic modulus, G', was hardly dependent on frequency, indicating a stable gel structure. With exception of rice starch gels, the presence of protein in all mixed starch/protein preparations decreased the tan $\delta$ regardless of the protein type. The addition of protein led to a network that shifted to a more elastic-like behaviour and a more structured gel (Ribotta et al., 2012). The tapioca starch gels had the highest values of loss tangent, which means the viscous modulus was higher with respect to the elastic one than in the remaining systems (Da Silva and Rao, 2007). The elastic moduli of tapioca gels also showed the highest dependence on frequency, as shown by the highest "a" exponent values, among the gels made by different starch sources.

\subsubsection{Rheological properties of gels prepared at autoclaving temperatures $\left(120^{\circ} \mathrm{C}\right)$}

Table 2 also shows the values of viscoelastic parameters for gels casted at $120^{\circ} \mathrm{C}$. At this temperature, potato starch gave the highest consistency gels. Acidification of aqueous dispersions of potato starch increased the elastic moduli (59\%) and decreased $\tan \delta$ (44\%), meaning a reinforcement of the gel network structure obtained at $120^{\circ} \mathrm{C}$, while no effect was observed for all other starch gels. The high phosphate content of potato starch might be the origin of the different effect of $\mathrm{pH}$ on gels prepared at such harsh conditions due to the formation of a counter-ion layer at the phosphate groups on the surface of the potato starch granules (Muhrbeck and Eliasson, 1987). The presence of protein in general reinforced all the gels prepared at $120^{\circ} \mathrm{C}$ (Table 2). Rice and tapioca gels exhibited a significant increase in the elastic and viscous moduli when protein was added, with increments being larger when EA was incorporated (190\% and $88 \%$ for rice and $234 \%$ and $151 \%$ for tapioca for $\mathrm{G}_{1}{ }^{\prime}$ and $\mathrm{G}_{1}{ }^{\prime}$, , respectively) than with SPI (33\% and $26 \%$ for rice and $47 \%$ and $37 \%$ for tapioca). Incorporation of EA also affected the potato starch gels (distilled water as medium), increasing their elastic modulus, $\mathrm{G}_{1}{ }^{\prime}{ }^{\prime}(34 \%)$, and decreasing the loss tangent (30\%). Lowering the $\mathrm{pH}$ of protein-enriched starch suspensions had a different effect depending on the protein and the starch source, as revealed by the significant interaction effects (starch $\mathrm{x}$ protein $\mathrm{x} \mathrm{pH}$ ) (Table 2). Acidification of the SPI-potato starch dispersions strengthened the structure of the gel formed as shown by the increase of elastic modulus (77\%) and the decreased $\tan \delta$ value (33\%). On the contrary, acidification of rice gels supplemented with SPI, resulted in reduction of both elastic and viscous moduli (34\% and $24 \%$, respectively) with a concomitant increase in $\tan \delta(15 \%)$. The opposite effect was reported in the previous section for rice and potato gels at $90^{\circ} \mathrm{C}$, implying that the temperature of gel setting also plays an important 
role on the viscoelastic properties of mixed starch/protein gel systems, especially when SPI is present in the composite gel matrix.

\subsection{Microscopy of starch granule dispersions and gels}

CLSM imaging has been employed to investigate the microstructure of starch dispersions and starch gels formed with or without addition of egg albumin and soy protein isolate at $90^{\circ} \mathrm{C}$ and $120^{\circ} \mathrm{C}$ (Fig.4). CLSM did not reveal differences between aqueous and acidified granular starch dispersions (pictures are not shown). The micrographs showed the typical size and shape of starch granules for each species which have often been reported in the literature (Delcour and Hoseney, 2010; Schirmer et al., 2013; Van de Velde et al., 2002). Potato starch displayed mostly large oval or round granules, ranging from 15 to $100 \mu \mathrm{m}$, compared to the much smaller rice starch granules which varied in the range of 2-8 $\mu \mathrm{m}$. Moreover, rice and tapioca starch consisted of a mixture of truncated and round granules with the largest granules being round and the smaller ones truncated, while the shape of tapioca starch granules was more uniform and their size varied between 5 and $40 \mu \mathrm{m}$.

Upon heating the starch or protein-starch dispersions, the type of starch and composition of the mixed dispersions had a large impact on the system's microstructure (Biliaderis, 2009). That is, heating a diluted starch or protein-starch dispersion in distilled water or in acid medium, at 90 or $120^{\circ} \mathrm{C}$ for $7 \mathrm{~min}$, resulted in pronounced deformation (swelling, rupture and collapse) of the granules with a subsequent amylose leaching out of the swollen granular structure, as shown in Fig.4. The microstructures of the different gels seem to be dependent on the type of starch used, the addition of protein, and the composite mixture of the biopolymers involved in the mixed gel networks. Specifically, upon heating, when the dispersions consisted of solely starch, discrete structural elements with a spherical-like shape were detected. The size and the number of these entities were dependent on the starch type and the temperature employed for gelation; i.e., the gels from rice starch had more pronounced structural features which became more globe-shaped and of smaller size at $120^{\circ} \mathrm{C}$. On the other hand, the potato starch gels displayed more uniform ('smooth') microstructure than the other two types of starch.

The microscopic observations clearly showed that the incorporation of proteins in starch dispersions resulted in different microstructures. As can be seen in Fig.4, the final microstructure was not predominantly determined by one of the individual biopolymers used in this study. Although equal amounts of protein and starch were used in making the primary dispersions, the divergent microstructures formed indicate the strong impact of each specific combination of the two biopolymers involved in the final mixed gelling system. 


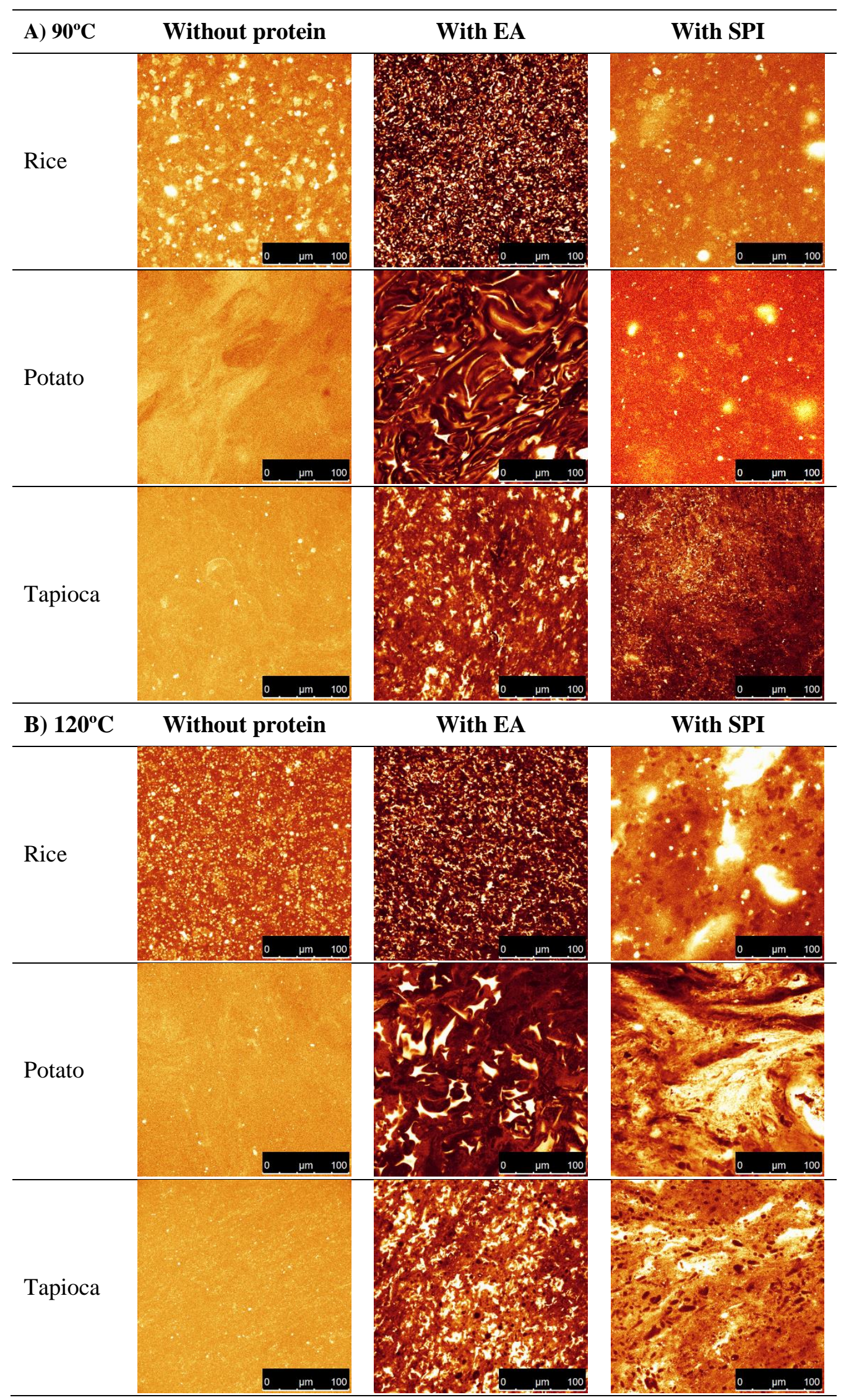

Figure 4. Confocal laser scanning micrographs of starch gels prepared at $90^{\circ} \mathrm{C}(\mathrm{A})$ and $120^{\circ} \mathrm{C}$ (B). EA: Egg albumin; SPI: Soy protein isolate. 


\section{Conclusions}

The addition of egg albumin and soy protein isolate at $10 \%$ (by weight in the solid starch-protein mixtures) combined with a reduction of $\mathrm{pH}$ to 4.5 proved to be an efficient way to modify the thermal and rheological properties of rice, potato and tapioca starches and starch gels. Gels prepared at $120{ }^{\circ} \mathrm{C}$ were much weaker (lower consistency and more prone to break-down upon deformation) than those formed at $90{ }^{\circ} \mathrm{C}$; the rice starch being the most sensitive to increasing gelification temperature and potato the most resistant. In general, proteins worked as structure enhancing agents at both temperatures; in gels prepared at $120^{\circ} \mathrm{C}$ the strengthening effect was more pronounced. In contrast, acidification weakened the structure of these gels. It can be concluded that both $\mathrm{pH}$ and addition of exogenous proteins are useful approaches to modify the functional properties of gel-like starchy food products. The rheological observations made in this study could be helpful in attempting to modify gluten-free formulations, which are mostly based on non-wheat cereal or tuber starches to optimize the end-product quality attributes (texture, microstructure, thermal stability of autoclaved food products to extend their shelf life). Further studies are needed to clarify the role of acidification into heated starch-protein mixtures by employing a range of structure probing analytical techniques (calorimetry, various rheological tests, chromatography, different spectroscopies, etc.) to unravel the molecular interactions among the hydrocolloids involved and thereby fine tune end-product quality.

\section{Acknowledgement}

The authors gratefully acknowledge the financial support of the Spanish Institution Ministerio de Economia y Competitividad and the European Regional Development Fund (FEDER) (Projects AGL2012-35088 and AGL2015-63849-C2-2-R) and Consejeria de Education (Junta de Castilla y Leon) / FEDER (Project VA072P17). Marina Villanueva thanks the Junta de Castilla y León for the doctorate grant.

\section{References}

Abebe, W. and Ronda, F. (2014). Rheological and textural properties of tef [Eragrostis tef (Zucc.) Trotter] grain flour gels. Journal of Cereal Science, 60, 122-130.

Biliaderis, C. G. (1983). Differential Scanning Calorimetry in Food research-A Review. Food Chemistry, 10(4), 239-265.

Biliaderis, C.G. (2009). Structural transitions and related physical properties of starch. In R L. Whistler and J. N. BeMiller (Eds.), Starch: Chemistry and Technology, $3^{\text {rd }}$ edition (p. 293-372), Academic Press, Burlington, MA, USA.

Blanco, C. A., Ronda, F., Pérez, B., \& Pando, V. (2011). Improving gluten-free bread quality by enrichment with acidic food additives. Food Chemistry, 127, 1204-1209.

Brownsey, G. J., Orford, P. D., Ridout, M. J., \& Ring, S. G. (1989). A Study of the Mechanical Behaviour and Microstructure of a mixed starch-egg-White Protein Gel. Food Hydrocolloids, 3(1), 7-17.

Burrell, M. (2003). Starch: the need for improved quality or quantity - an overview. Journal of Experimental Botany, 54, 382.

Carlstedt, J., Wojtasz, J., Fyhr, P., \& Kocherbitov, V. (2015). Understanding Starch Gelatinization: The Phase Diagram Approach. Carbohydrate Polymers, 129, 62-69. 
Chang, C., Niu, F., Su, Y., Qiu, Y., Gu, L., \& Yang, Y. (2016). Characteristics and Emulsifying Properties of Acid and Acid-Heat Induced Egg White Protein. Food Hydrocolloids, 54, $342-350$.

Chen, W., Zhou, H., Yang, H., \& Cui, M. (2015). Effects of Charge-Carrying Amino Acids on the Gelatinization and Retrogradation Properties of Potato Starch. Food Chemistry, 167, 180-184.

Christianson, D.D., Casiraghi, E.M., Bagley, E.B. (1986). Deformation and Fracture of Wheat, Corn and Rice Starch Gels in Lubricated and Bonded Uniaxial Compression. Carbohydrate Polymers, 6, 335-348.

Colussi, R., El Halal, S.L.M., Pinto, V.Z., Bartz, J., Gutkoski, L.C., Zavareze, E., Guerra-Dias, A.R. (2015). Acetylation of rice starch in an aqueous médium for use in food. LWTFood Science and Technology, 62, 1076-1082.

Crockett, R., Ie, P., \& Vodovotz, Y. (2011). Effects of soy protein and egg white solids on the physicochemical properties of gluten-free bread. Food Chemistry, 129, 84-91.

da Cruz Francisco, J., Silverio, J., Eliasson, A., \& Larsson, K. (1996). A Comparative Study of Gelatinization of Cassava and Potato Starch in an Aqueous Lipid Phase (L2) Compared to Water. Food Hydrocolloids, 10(3), 317-322.

Da Silva, J.A.L. and Rao, M. A. (2007). Rheological Behavior of Food Gels, In M.A. Rao (Ed.), Rheology of Fluid and Semisolid Foods Principles and Applications (pp. 339-401). New York: Springer Science+Business Media.

Delcour, J.A. and Hoseney, R.C. (2010). Starch, In J.A. Delcour and R.C. Hoseney (Eds.), Principles of Cereal Science and Technology, $3^{\text {rd }}$ Edition (pp. 23-51). St. Paul: AACC International, Inc..

Doublier, J.L., Llamas, G., Le Meur, M. (1987). A Rheological Investigation of Cereal Starch Pastes and Gels. Effect of Pasting Procedures. Carbohydrate Polymers, 7, 251-275.

Eliasson, A.-C., (1994). Interactions between starch and lipids studied by DSC. Thermochimica Acta 246, 343-356

Hibi, Y. (2002). Effects of salt, sugar and vinegar on melting of the amylose-lipid complex in rice starch. Journal of Home Economics of Japan, 53, 805-810.

Hoover, R. (2001). Composition, molecular structure, and physicochemical properties of tuber and root starches: a review. Carbohydrate Polymers, 45, 253-267.

Jayaram, V. B., Cuyvers, S., Verstrepen, K. J., Delcour, J. A., \& Courtin, C. M. (2014). Succinic acid in levels produced by yeast (Saccharomyces cerevisiae) during fermentation strongly impacts wheat bread dough properties. Food Chemistry, 151, 421-428.

Jekle, M., \& Becker, T. (2012). Effects of Acidification, Sodium Chloride, and Moisture Levels on Wheat Dough: I. Modeling of Rheological and Microstructural Properties. Food Biophysics, 7, 190-199.

Kasai, M., Tanihata, S., Ohishi, K., Shimada, A., \& Hatae, K. (2001). Effect of acetic acid on the palatability and physicochemical properties of cooked rice. Journal of Home Economics of Japan, 52, 1091-1097. 
Krystyjan, M., Ciesielski, W., Khachatryan, G., Sikora, M., \& Tomasik, P. (2015). Structure, Rheological, Textural and Thermal Properties of Potato Starch - Inulin Gels. LWT - Food Science and Technology, 60(1), 131-136.

Mandala, I., \& Kapsokefalou, M. (2011). Gluten-Free Bread: Sensory, Physicochemical, and Nutritional Aspects. In V. R. Preedy, R. R. Watson, \& V. B. Patel (Eds.), Flour and breads and their fortification in health and disease prevention, (pp. 161-169), Elsevier/Academic Press, Burlington, MA, USA.

Marco, C., Rosell, C.M., (2008a). Effect of different protein isolates and transglutaminase on rice flour properties. Journal of Food Engineering, 84, 132-139.

Marco, C., Rosell, C.M. (2008b). Functional and rheological properties of protein enriched gluten free composite flours. Journal of Food Engineering, 88, 94-103.

Matos, M.E., Rosell, C.M., (2015). Understanding glute-free dough for reaching breads with physical quality and nutritional balance. J. Sci. Food Agric. 95: 653-661

Moore, M., Dal Bello, F., \& Arendt, E. K. (2008). Sourdough fermented by Lactobacillus plantarum FST 1.7 improves the quality and shelf life of gluten-free bread. European Food Research and Technology, 226, 1309-1316.

Muhrbeck, P. \& Eliasson, A. (1987). Influence of pH and Ionic Strength on the Viscoelastic Properties of Starch Gels. A Comparison of Potato and Cassava Starches. Carbohydrate Polymers, 7(4), 291-300.

Ohishi, K., Kasai, M., Shimada, A., \& Hatae, K. (2003). Effect of acetic acid added to cooking water on the dissolution of proteins and activation of protease in rice. Journal of Agricultural and Food Chemistry, 51, 4054-4059.

Ohishi, K., Kasai, M., Shimada, A., \& Hatae, K. (2007). Effects of Acetic Acid on the Rice Gelatinization and Pasting Properties of Rice Starch during Cooking. Food Research International, 40(2), 224-231.

Ribotta, P. D., Colombo, A., \& Rosell, C. M. (2012). Enzymatic Modifications of Pea Protein and its Application in protein-cassava and Corn Starch Gels. Food Hydrocolloids, 27(1), 185190.

Ribotta, P. D. \& Rosell, C. M. (2010). Effects of Enzymatic Modification of Soybean Protein on the Pasting and Rheological Profile of starch-protein Systems. Starch-Stärke, 62(7), 373383.

Ronda, F., Oliete, B., Gómez, M., Caballero, P. A., \& Pando, V. (2011). Rheological Study of Layer Cake Batters made with Soybean Protein Isolate and Different Starch Sources. Journal of Food Engineering, 102(3), 272-277.

Ronda, F., Villanueva, M., \& Collar, C. (2014). Influence of Acidification on Dough Viscoelasticity of Gluten-Free Rice Starch-Based Dough Matrices Enriched with Exogenous Protein. LWT - Food Science and Technology, 59(1), 12-20.

Roos, Y.H. (1995). Glass transition-related physicochemical changes in foods. Food Technology, $10,97-102$. 
Schirmer, M., Höchstötter, A., Jekle, M., Arendt, E., \& Becker, T. (2013). Physicochemical and Morphological Characterization of Different Starches with Variable amylose/amylopectin Ratio. Food Hydrocolloids, 32(1), 52-63.

Singh, N., Singh, J., Kaur, L., Singh Sodhi, N., \& Singh Gill, B. (2003). Morphological, Thermal and Rheological Properties of Starches from Different Botanical Sources. Food Chemistry, 81(2), 219-231.

Tabilo-Munizaga, G. \& Barbosa-Cánovas, G. V. (2005). Rheology for the Food Industry. Journal of Food Engineering, 67, 147-156.

Van de Velde, F., van Riel, J., \& Tromp, R. H. (2002). Visualisation of Starch Granule Morphologies using Confocal Scanning Laser Microscopy (CSLM). Journal of the Science of Food and Agriculture, 82(13), 1528-1536.

Villanueva, M., Mauro, R. R., Collar, C., \& Ronda, F. (2015). Acidification of Protein-Enriched Rice Starch Doughs: Effects on Breadmaking. European Food Research and Technology, 240(4), 783-794.

Walkenström, P. \& Hermansson, A. (1998). Effects of Shear on Pure and Mixed Gels of Gelatin and Particulate Whey Protein. Food Hydrocolloids, 12(1), 77-87. 